\title{
ERRATUM
}

\section{Transhepatic Embolization of a Recanalized Congenital Hepatic Arterioportal Fistula with NBCA and Coils}

\author{
B.E. Cil, S. Cekirge, M.N. Ozmen, F. Balkanci, A. Besim \\ Department of Radiology, Hacettepe University School of Medicine, Sihhiye 06100, Ankara, Turkey
}

Re: CVIR 27(2) 172-174 (2004) [DOI: 10.1007/s00270-0030152-4] The author regrets that the following co-authors were

Correspondence to: B.E. Cil, M.D., Guvenevler Ic Sokak No: 4/5, Kavoklidere 06541, Ankara, Turkey; email: barbaroscil@ hotmail.com mistakenly omitted in the original print version of this article. The authors are: B.E. Cil, S. Cekirge, M.N. Ozmen, F. Balkanci, and A. Besim. The authors, along with their affiliation, appear correctly above. 